NBER WORKING PAPER SERIES

\title{
PSYCHIATRIC DISORDERS AND LABOR MARKET OUTCOMES: EVIDENCE FROM THE NATIONAL LATINO AND ASIAN AMERICAN STUDY
}

\author{
Pinka Chatterji \\ Margarita Alegria \\ Mingshan Lu \\ David Takeuchi \\ Working Paper 11893 \\ http://www.nber.org/papers/w11893 \\ NATIONAL BUREAU OF ECONOMIC RESEARCH \\ 1050 Massachusetts Avenue \\ Cambridge, MA 02138 \\ December 2005
}

Corresponding author: Pinka Chatterji, Ph.D., Center for Multicultural Mental Health Research, Cambridge Health Alliance/Harvard Medical School, 120 Beacon Street 4th Floor, Somerville MA 02143 617-503-8449 (phone), 617-503-8430 (fax), pchatterji@charesearch.org (e-mail). The NLAAS data used in this analysis was provided by the Center for Multicultural Mental Health Research at the Cambridge Health Alliance. The NLAAS received approval from IRBs at Cambridge Health Alliance, the University of Washington, and the Institute for Social Research at the University of Michigan. The project was supported by NIH Research Grant \# U01 MH62209 funded by the National Institute of Mental Health as well as SAMHSA/CMHS. Chatterji also acknowledges support from Grant K01 AA000328-03 from the National Institute of Alcohol Abuse and Alcoholism. Lu thanks the Alberta Heritage Foundation for Medical Research and Institute of Health Economics for financial support. We thank Zhun Cao, Naihua Duan, Thomas McGuire, Richard Scheffler, Ken Wells, Dhaval Dave, seminar participants at the Academy Health 2004 Annual Research meeting, the Third International Conference on Urban Health, and the Centre for Applied Economic Research at University of New South Wales, Sydney for their valuable comments and suggestions. The authors alone are responsible for the analysis and conclusions. The views expressed herein are those of the author(s) and do not necessarily reflect the views of the National Bureau of Economic Research.

(C2005 by Pinka Chatterji, Margarita Alegria, Mingshan Lu, David Takeuchi. All rights reserved. Short sections of text, not to exceed two paragraphs, may be quoted without explicit permission provided that full credit, including (C) notice, is given to the source. 
Psychiatric Disorders and Labor Market Outcomes: Evidence from the National Latino and Asian American Study

Pinka Chatterji, Margarita Alegria, Mingshan Lu, David Takeuchi

NBER Working Paper No. 11893

December 2005

JEL No. I1

\section{ABSTRACT}

This paper investigates to what extent psychiatric disorders and mental distress affect labor market outcomes among ethnic minorities of Latino and Asian descent, most of whom are immigrants. Using data from the National Latino and Asian American Study, we examine the labor market effects of meeting diagnostic criteria for any psychiatric disorder in the past 12 months as well as the effects of psychiatric distress in the past year. Among Latinos, psychiatric disorders and mental distress are associated with detrimental effects on employment and absenteeism, similar to effects found in previous analyses of mostly white, American born populations. Among Asians, we find mixed evidence that psychiatric disorders and mental distress detract from labor market outcomes.

Pinka Chatterji

Center for Multicultural Mental Health Research

Cambridge Health Alliance/Harvard Medical School

120 Beacon Street 4th Floor

Somerville MA 02143

and NBER

pchatterji@charesearch.org

Margarita Alegria

Center for Multicultural Mental Health Research

Cambridge Health Alliance/Harvard Medical School

120 Beacon Street 4th Floor

Somerville MA 02143

malegria@charesearch.org
Mingshan Lu

Department of Economics

University of Calgary

2500 University Drive NW, SS 440

Calgary, Alberta, Canada T2N 1N4

lu@ucalgary.edu

David Takeuchi

Department of Sociology

and School of Social Work

University of Washington

4101 15th Avenue NE

Seattle WA 98105-6299

dt5@u.washington.edu 


\section{Introduction}

Untreated mental illness in the workplace is a critically important and costly problem worldwide [1]. Psychiatric disorders are highly prevalent, affecting about 26 percent of the US population in a given year [2], frequently are recurrent and debilitating [3], and can impair workplace productivity by affecting factors such as memory, concentration, decisiveness, motivation, and social relations. In the US, a very large portion of the total cost of mental illness - about 77 million dollars, or 48 percent, in 1992 -has been attributed to reduced workplace productivity [4-5]. There also is substantial empirical evidence that psychiatric disorders are associated with a range of specific, adverse labor market outcomes, including unemployment, reduced labor supply, absenteeism, disability-related work leaves, lower perceived workplace productivity, and reduced earnings [6-12].

Much of the recent research on psychiatric disorders and labor market outcomes in the US context is based on two data sources, the epidemiologic catchment area (ECA) surveys, which were conducted in five communities during the early 1980's, and the National Comorbidity Survey (NCS), which took place on a national scale during the early 1990's. The ECA surveys and the NCS are unique in that they are large, population-based surveys that include diagnostic interviews for a range of psychiatric illnesses. However, these surveys were administered to English speaking respondents only, and, as a result, they excluded large numbers of first generation immigrants with limited English proficiency. Although the ECA and NCS do include English-proficient non-white respondents, sample sizes for ethnic minorities, particularly Asians, and immigrants are small [13].

The US labor force, on the other hand, reflects changes in the population as a whole and is increasingly comprised of Latinos, Asian-Americans, and immigrants. In 2000, Latino and 
Asian Americans made up about 16 percent of the US labor force [14]. The number of Latinos in the labor force is expected to increase by more than 5.5 million by 2010 , increasing to 20.9 million workers, compared to 15.4 million workers in 2000. Although the Asian population remains relatively small, about 3.2 million Asian workers will enter the labor force by 2010 - a net increase of 44 percent from the year 2000 [14]. Foreign born persons represent 14 percent of the labor US force [15]. Given the growing size of the Latino, Asian American, and immigrant populations in the US and their increasing presence in the labor force, it is essential that we understand how mental health impacts labor market success for these groups.

This study is the first to investigate the effects of psychiatric disorders and symptoms of mental distress on labor market outcomes using a national sample of Latino and Asian Americans. Data come from the National Latino and Asian American Study (NLAAS), a national psychiatric epidemiologic study conducted to measure psychiatric disorders and mental health service usage in a US representative sample of Asians and Latinos [16]. Unlike most population-based surveys, the NLAAS provides detailed and high quality diagnostic data on mental health status, as well as information on demographics, chronic physical health conditions, and labor market outcomes. We consider the effects of meeting diagnostic criteria for any psychiatric disorder in the past 12 months, as well as the effects of three broad classes of disorders (affective disorders, anxiety disorders and substance use disorders). We also estimate the effect of the K10 measure of psychiatric distress on labor market outcomes. The labor market outcomes analyzed are current employment status, the number of weeks worked in the past year among those who are employed, and having at least one work absence in the past month among those who are employed. 
The findings suggest that among Latinos, having any recent psychiatric disorder is associated with a decrease in the probability of being employed by about 10 percentage points for males and by about 23 percentage points for females. The magnitudes of these effects are in the range of those found for mostly White, native-born populations. Moreover, recent psychiatric disorders are associated with an increase the probability of at least one work absence in the past month by 19 percentage points for employed Latino males and by 14 percentage points for employed Latino females. Higher levels of mental distress are associated with both unemployment and work absence among Latinos. Psychiatric disorders and distress, however, do not appear to reduce the number of weeks worked by employed Latinos. Moreover, in the Asian samples, we find suggestive, but much less consistent, evidence that psychiatric disorders and mental distress are associated with any of the labor market outcomes studied.

\section{Background}

There is considerable evidence from the economics literature that psychiatric disorders detract from earnings, employment, and work hours. Frank and Gertler [8], for example, use data on men from the Baltimore ECA and find that mental distress is associated with a 21 percent reduction in earnings. Mental distress in this study is captured by whether or not the individual has at least two of the following three indications of psychiatric disorder - last year DSMIII diagnosis, at least four symptoms of psychiatric distress as measured on the General Health Questionnaire, and at least one self-reported disability day [8].

Ettner et al. [9] build on this study by using the NCS, which includes a nationally representative sample, and by addressing the possibility that unobserved factors may confound an observed relationship between psychiatric disorders and labor market outcomes. They report that among both men and women, a diagnosis of any psychiatric disorder during the past 12 
months is associated with a reduction of about 11 percentage points in the probability of being employed. Ettner et al. also find some effects of psychiatric disorders on earnings and hours worked, but these associations were more sensitive to the model specification, sample and estimation methods used.

Alexandre and French [6] also find that depression is associated with poor labor market outcomes, reducing the probability of being employed by about 19 percentage points and decreasing the number of weeks worked in the past year by 7-8 weeks. The measure of depression in this study is a self-rated depression scale rather than a DSM diagnosis. Although this measure has some disadvantages compared to a diagnostic interview, the sample is ethnically diverse -- it includes low-income adults from Miami, most of whom are AfricanAmerican or Latino, and 19 percent of whom are foreign born.

In addition to having negative effects on employment, labor supply, and earnings, there also is evidence that psychiatric disorders detract from on-the-job performance by impairing productivity and causing work absences. Kouzis and Eaton [11], using 1981 data from the Baltimore ECA, find that psychiatric disorders are strongly associated with work absences among employed persons. Kessler et al [12] and Kessler and Frank [7] confirm these findings using data from the NCS and the Midlife Development in the US Survey. Kessler et al. [12] find that depressed employees report between 1.5 and 3.2 more short-term disability days in the past month than other employees, defined as full or partial days when the respondent could not work. Kessler and Frank [7] also show that workers with more than one psychiatric disorder have more disability days than workers with one or no psychiatric disorders. Berndt et al. [10] offer further evidence that mental illness interferes with the ability to carry out work functions. Using data 
from a clinical trial involving chronically depressed patients, they report that reduction in the severity of depression improves patient perceptions about work performance.

The ECA and NCS datasets, which are used in much of the previous research on psychiatric disorders and labor market outcomes, are community-based and national samples. The samples do include some English-speaking, racially and ethnically diverse respondents, but individuals who were not English proficient at the time of the surveys were not sampled. This restriction may have affected the composition of these samples considerably.

In the NLAAS, about 50 percent of Latinos and 35 percent of Asians rated their English proficiency as fair or poor, which may have excluded them from English diagnostic assessments [16]. Moreover, ECA and NCS sample sizes generally do not permit separate estimation of the effects of psychiatric disorders on labor market outcomes by ethnicity and gender. These data constraints limit our understanding of how psychiatric disorders affect labor market outcomes among Latinos and Asian-Americans, ethnic groups in the US that are projected to triple in size by 2050 [17].

Estimating models by ethnicity and gender groups, and including non-English proficient individuals, is important for at least two reasons. First, ethnic minorities and immigrants generally work in different types of occupations than whites because of historical and institutional factors, and, in the case of immigrants, because of the context of exit from their home countries and the time it takes to assimilate into the labor market [18]. In 2003, 35.5 percent of the white employed population had occupations classified as "management, professional and related," the occupational class associated with the highest levels of autonomy and social standing. In 2003, only 17.0 percent of employed Latinos had occupations in this category, while the number is 43.3 percent among employed Asians. Employed Latinos are much 
more likely to work in service sector jobs than employed whites and Asians [19]. Asians are disproportionately represented in computer and mathematical occupations, as well as in engineering and life, physical and social science occupations, which reflects the fact that Asians are more likely than any other racial/ethnic group to have a college degree [20]. Symptoms of a psychiatric disorder may be less likely to visibly affect job performance in occupations with high levels of autonomy and privacy. On the other hand, high-status jobs may require more concentration and cognitive ability than lower-status jobs, making it harder to function when dealing with a mental illness [7].

Ethnic and racial minorities also may face different labor market consequences of mental illness than whites because of labor market discrimination. Discrimination may result from place of birth, language proficiency or accent, skin color or culture. If labor market discrimination exists, the negative consequences of both having a psychiatric disorder and being an ethnic minority may be compounded in the labor market. While there is considerable evidence that inter-racial and ethnic earnings differentials exist, the source of these differentials - and whether labor market discrimination plays a role - is controversial [21]. While this analysis cannot test for discrimination, estimating the effects of psychiatric disorders on labor market outcomes in a large sample of Latino and Asian Americans allows one to gauge whether these groups face different labor market impacts than majority populations.

\section{Methods}

In the human capital framework, individuals embody a stock of productive capital that determines their productivity in the market. This stock is accumulated throughout the lifetime through schooling, training, work and other experiences [22-24]. The onset of a psychiatric illness, particularly during youth, may interfere with the process of human capital accumulation, 
such as by disrupting educational plans. In this way, psychiatric disorders may affect employment and performance on the job indirectly, via reduced education [25]. Psychiatric illness, however, also may affect job prospects and productivity directly through its effects on motivation, judgment, cognition and social interactions (see Chapter 2, Mental Health: A Report of the Surgeon General for signs and symptoms of common disorders [26]). We seek to estimate this latter effect - the direct effect of current psychiatric disorders on labor market outcomes among adults - while controlling for other human capital pathways through which mental illness may affect labor market outcomes indirectly.

Guided by the above theoretical framework, we adopt models of the following type:

$$
E_{i}=\alpha+X_{i} \beta+M H_{i} \delta+\varepsilon_{i}
$$

where $E_{i}$ is a measure of individual i's labor market outcomes, $\alpha$ is an intercept, $X_{i}$ is a vector of observable exogenous individual characteristics that may affect labor market success, $\mathrm{MH}$ is a measures of psychiatric illness, and $\varepsilon_{\mathrm{i}}$ is an error term. $\beta$ and $\delta$ are the unknown parameters of interest to be estimated.

Empirically, estimating the effect of psychiatric illness on labor market outcomes $(\delta)$ is complicated by two factors. First, the causation between psychiatric disorders and labor market outcomes may run in the opposite direction, with employment factors influencing mental distress. Job loss, for example, may lead to subsequent mental health problems [27]. Second, the relationship between psychiatric disorders and labor market outcomes may be confounded by an unmeasured, causal factor, such as a stressful life event. It may be difficult to measure some important correlates of mental illness using secondary data, and these unmeasured correlates of mental illness also may affect labor market outcomes directly. In both of these cases, estimating 
the coefficients using standard methods such as OLS would violate a central assumption underlying the classical linear regression model framework, which is that the right-hand side variables should be exogenous with respect to the error term [28].

We use three approaches to deal with this problem. Our first approach is to use data on observed characteristics to proxy unobserved characteristics to the fullest extent possible. Specific details about the covariates included in the models are described in the next section of the paper. Notably, the NLAAS includes information on chronic physical health conditions, which frequently co-exist with psychiatric disorders and could confound an observed association between psychiatric disorders and adverse labor market outcomes [29]. We use a standard OLS model for continuous dependent variables, and a standard probit model for binary outcomes to estimate (1).

Our second empirical approach is to estimate standard OLS and probit models that include a measure of any prior psychiatric illness in addition to a measure of last year psychiatric illness or distress, which is the main covariate of interest. Prior psychiatric condition is defined as the existence of any lifetime diagnosis with most recent symptoms exhibited prior to the previous year. This measure is a proxy for unobserved, indirect channels through which previous mental illness may affect current labor market outcomes. Regardless of an individual's current mental status, prior symptoms may affect current work performance indirectly. For example, previous mental health problems may have interrupted the development of social skills that are important in the workplace. Even our detailed set of covariates would not account for this factor, and it could confound an observed association between recent mental illness and labor market outcomes. When we include both recent and prior measures of psychiatric illness in the same model, we essentially are isolating the impact of incident mental illness or distress, 
above and beyond one's previous experiences with mental illness, on current labor market outcomes.

These two approaches use observed data to proxy unobserved factors that might confound an association between recent psychiatric disorders and labor market outcomes. The methods do not directly address the problem of reverse causality. Also, important correlates of psychiatric disorders and labor market outcomes still may be left out of the model. For this reason, we implement a third approach, which is to use empirical methods that directly address the possibility that unobserved factors may exist that are associated with both psychiatric disorders/distress and labor market outcomes.

Where the labor market outcome measure is continuous, we use the two-stage least squares (TSLS) method:

Stage 1: $M H_{i}=\alpha_{2}+X_{i} \beta_{2}+Z_{i} \xi+\varepsilon_{2 i}$

Stage 2: $E_{i}=\alpha_{1}+X_{i} \beta_{1}+\hat{M H}_{i} \delta+\varepsilon_{1 i}$

in which $\hat{M H}_{i}$ is the predicted value from estimating psychiatric disorder on observable individual characteristics $\left(\mathrm{X}_{\mathrm{i}}\right)$ and instrumental variables $\left(\mathrm{Z}_{\mathrm{i}}\right)$ in stage 1 .

In the case of binary labor market outcome and psychiatric disorder variables, we use a bivariate probit model:

$$
\begin{aligned}
& E_{i}^{*}=\alpha_{1}+X_{i} \beta_{1}+M H_{i} \delta+\varepsilon_{1 i} \\
& M H_{i}^{*}=\alpha_{2}+X_{i} \beta_{2}+Z_{i} \xi+\varepsilon_{2 i} \\
& E_{i}=1 \text { if } E_{i}^{*} \geq 0
\end{aligned}
$$




$$
M H_{i}=1 \text { if } M H_{i}^{*} \geq 0
$$

Under the bivariate probit model, employment $\left(\mathrm{E}_{\mathrm{i}}\right)$ and psychiatric illness $\left(\mathrm{MH}_{\mathrm{i}}\right)$ are simultaneously specified by the following likelihood function [28]:

$$
\operatorname{Pr}\left(E_{i}=1, M H_{i}=1\right)=\Phi\left(X_{i} \beta_{1}+M H_{i} \delta, X_{i} \beta_{2}+Z_{i} \xi, \rho\right)
$$

where $\Phi$ is the bivairate cumulative distribution function and $\rho=\operatorname{cov}[\varepsilon, \eta]$ is the correlation coefficient. The model is estimated using maximum likelihood. (For recent studies using the bivariate probit model, see MacDonald and Shields [30], Evans and Schwab [31], and Goldman [32]).

The practical challenge of implementing the TSLS method and the bivariate probit model is that in order to identify the labor market outcome equation, there must be at least one variable that affects mental illness, but that is also exogenous and not directly related to labor market outcomes $\left(\mathrm{Z}_{\mathrm{i}}\right)$. The identifying variable or variables should be reasonably good predictors of mental illness. In the case of TSLS, a low first stage F-statistic for the identifying instrumental variables may suggest that TSLS estimates are no better than biased OLS estimates [33-36]. Similarly, if the identifying variables are poor predictors of mental illness, the bivariate probit model does not work well, yielding imprecise estimates (see Rashad and Kaestner [37]).

Previous work on mental health (including substance abuse) and labor market outcomes have employed a large range of identifying variables, mostly used in the context of instrumental variables estimation. Some examples are parental alcohol dependency [38] or parental history of mental health problems [9]; number of childhood psychiatric disorders [9]; long-term non-acute illnesses such as asthma or diabetes [30, 39]; religiosity [6, 30, 39-41]; social support [6, 42]; and state-level alcohol and illicit drug policies and prices [43-44]. Following the above literature, we 
test and use three identifying instruments in our study $\left(\mathrm{Z}_{\mathrm{i}}\right):(1)$ the number of psychiatric disorders with early onset (before age 18); (2) whether the respondent attends religious services at least weekly; and (3) whether the respondent often uses spiritual or religious means (such as praying, meditation, or speaking to a religious provider) to handle problems.

The number of psychiatric disorders with onset before age 18 should be a good predictor of current psychiatric disorders because of the chronic nature of psychiatric illness. Early psychiatric problems may interfere with schooling, and this factor in turn is likely to impact labor market outcomes as an adult. However, after controlling for education and a range of other covariates, early onset of mental illness would not be expected to have a direct effect on labor market outcomes. We use religiosity as a measure of individual social capital. Studies have shown that higher social capital is correlated with better mental health [39, 45-48].

One limitation of our study is that all three identifying variables are personal characteristics, and it is difficult to make a strong theoretical argument that they are exogenous. For example, as Alexandre \& French [6] note, it is possible that religious beliefs directly impact work habits, such as the number of hours worked. It is also possible that employment and business information is conveyed through networks developed through church activities, which may help one's career. We deal with this problem by carefully assessing whether the identifying variables as a group are reasonably strong predictors of mental illness, and if they can be validly excluded from the labor market outcomes equation. Moreover, because we lack a strong theoretical justification for the exogeneity of the identifying variables, we interpret the TSLS and bivariate probit results with caution, and we do not emphasize these findings. Instead, we focus on the standard estimation results and use the TSLS and bivariate probit findings as a check on the main results of the paper. 


\section{$4 \quad$ The National Latino and Asian American Study}

Data used in the study come from The National Latino and Asian American Study (NLAAS), a 2002-2003 survey of non-institutionalized Asian and Latin American adults residing in the coterminous United States. The goal of the survey was to measure psychiatric diagnoses and mental health service usage among Asian and Latino Americans. The NLAAS is a nationally representative household sample of 4,864 individuals ages 18 and over, including 2,554 Latinos, 2,095 Asians, and 215 Whites (who were not included in this paper). NLAAS interviews were conducted in English, Spanish, Chinese (Mandarin), Tagalog and Vietnamese, based on the respondents' language preferences. Originally, all interviews had been planned to be conducted in-person, but due to budgetary constraints, approximately 1,000 interviews were conducted by telephone. The weighted response rates for the NLAAS samples were: 73.2 percent for the total sample; 75.5 percent for the Latino Sample; and 65.6 percent for the Asian sample [49]. We limit the analysis samples to 2,228 Latino respondents (1,016 males and 1,212 females) and 1,818 Asians (864 males and 954 females) between 18 and 65 years old who are not in school at the time of the survey. All models are estimated separately by gender and broad ethnic group (Latino or Asian) with techniques that acknowledge the complex survey design. A fully interacted model of all covariates interacted with Latino ethnicity empirically supports our estimation based on ethnicity specific samples. There are statistically significant interactions between Latino and many key predictors of mental disorders, such as age, marital status, chronic health conditions and English language proficiency (results not shown).

We consider the following three, self-reported labor market outcomes as dependent variables in this analysis: (1) a dummy variable indicating whether or not the respondent is currently employed; (2) among employed individuals, the number of weeks during which the 
respondent was employed in the past year; and (3) among employed individuals, whether or not the respondent missed at least one day of work in the past month. The employment indicator was created from a survey question regarding the respondent's work situation "as of today." Employed persons include respondents who work full or part time and respondents who report that they are self-employed. In the employment models, the omitted category combines individuals who are unemployed with individuals who are out of the labor force, such as homemakers, early retirees and discouraged workers. (Students and persons over 65 are excluded from the analysis samples.) In order to distinguish the effects of mental illness on unemployment and out of labor force status, we experiment with some multinomial logit models that allow for three, qualitative categories as the dependent variable (out of labor force, unemployed, with employed as the omitted category). Results from this analysis are discussed later in the paper.

The NLAAS contains detailed information on psychiatric disorders that were collected by trained, lay interviewers using the World Mental Health Survey Initiative version of the World Health Organization Composite International Diagnostic Interview (WMH-CIDI). This fully structured diagnostic instrument is based on the criteria of the Diagnostic and Statistics Manual of Mental Disorders, Version 4 (DSM-IV). The CIDI has been tested extensively for test-retest reliability and validity [50-51]. The NLAAS includes prior, 12 month and 30 days diagnoses for a range of psychiatric disorders. The survey also includes scales of mental distress [51] and psychiatric impairment [52].

Our main measure of recent psychiatric disorder is a dummy variable indicating whether or not the respondent met diagnostic criteria for any psychiatric disorder in the past 12 months. Any psychiatric disorder includes the following diagnoses: (1) major depression; (2) dysthymia; 
(3) agoraphobia; (4) generalized anxiety disorder (GAD); (5) panic attack; (6) panic disorder; (7) social phobia; (8) alcohol abuse; (9) alcohol dependence; (10) illicit drug abuse; (11) illicit drug dependence; (12) post-traumatic stress disorder; (13) anorexia; and (3) bulimia. We also consider the effects of three broad classes of psychiatric disorders separately (any affective disorder, any anxiety disorder, any substance use disorder - see Table 1 for definitions of these disorder classes), and the effects of mental distress, on labor market outcomes. To capture mental distress, we use the respondent's continuous score on the K10, a 10 question scale of nonspecific psychological distress (see Kessler et al. [53] for a description of this scale). The K10 has demonstrated, strong psychometric properties in demographic sub-samples [53]. Because of multicollinearity between the psychiatric measures, we include each of the diagnosis and mental distress measures separately in the models.

Our models include a rich set of covariates that are intended to control for personal characteristics that may be correlated with both labor market outcomes and mental illness. These variables are: (1) sub-ethnicity (within the broader Latino and Asian categories); (2) age in years; (3) education (high school, at least some college, with high school dropout as the baseline); (4) marital status (married/cohabiting, widowed/divorced/separated with single as the baseline); (5) the number of children in the household; (6) whether the respondent is not English proficient; (7) immigrant; (8) US citizen; (9) a set of dummy indicators for current physical health conditions asthma, diabetes, chronic obstructive pulmonary disease, cancer, cardiovascular conditions; and (10) the state unemployment rate in the interview year. The sub-ethnicity variables for the Latino samples are: Puerto Rican; Cuban; and Mexican, with Other Latino as the baseline. For the Asian samples, the sub-ethnicity variables are: Chinese; Vietnamese; Filipino, with Other Asian as the baseline. The identifying variables used in the bivariate probit and TSLS models are 
two dummy indicators of frequent religious attendance (at least weekly) and often using religious means to handle life's problems, as well as a continuous measure of the number of psychiatric disorders with onset during childhood.

As described earlier, in some models we include measures of both prior and current disorder. Prior disorder is measured by a dummy variable indicating whether the respondent met lifetime diagnostic criteria for any psychiatric disorder, but whose most recent symptoms occurred prior to the past year. Thus, this variable excludes disorders and symptoms that occurred in the past 12 months. It is important to note that in the models where both prior and recent disorder measures are included as covariates, the number of incident cases is relatively small in some cases (e.g. number of cases where a respondent without any prior disorder develops a disorder in the past 12 months). The number of incident cases was 107 for Latino females, 48 for Latino males, 38 for Asian females, and 33 for Asian males.

Observations were dropped if they had missing information on employment status $(n=2)$, marital status $(n=2)$, English proficiency $(n=4)$, immigrant $(n=2)$, US citizen $(n=7)$, state unemployment rate $(n=2)$, religious service attendance $(n=14)$, reliance on religious means to deal with problems $(n=4)$, and K10 distress score $(n=1)$. In models of absences and labor supply, we also dropped respondents with missing information on work absences and the number of weeks worked.

Across the samples, 81 to 84 percent of males and 56 to 64 percent of females are currently employed (Table 1). In the female analysis samples, 27 to 36 percent of respondents are out of the labor force, which includes individuals who are homemakers, retired, disabled or not looking for work. Approximately 11 to 12 percent of males report being out of the labor force. Among employed respondents, the number of weeks worked in the past year ranged from 
about 47 to 50 weeks. In the male samples, 20 to 25 percent of respondents reported missing at least one day of work in the past month; among females, 26 to 27 percent responded missing at least one day of work in the past month.

The unemployment rate is about 8-9 percent in the female samples, and ranges from 5 to 8 percent in the male samples. The sample unemployment rates are consistent with national unemployment rates for Latinos during the time period when the NLAAS data were collected. In January 2003, the unemployment rate for Latino women age 20 and over was 8.4 percent, and the unemployment rate for Latino males age 20 and over was 7.5 percent [19]. Nationally, the unemployment rate for Asian males was 6 percent and the unemployment rate for females was 5 percent in 2002 .

Recent psychiatric conditions are relatively common in all four samples, with the highest rates among Latino females. Among Latino females, 17 percent meet diagnostic criteria for at least one psychiatric disorder in the past 12 months - a large proportion of these women are experiencing affective disorders (9 percent) and/or anxiety disorders (12 percent), but very few have a diagnosis of substance abuse or dependence (1 percent). Among Latino males, 14 percent have a 12 month DSM-IV diagnosis for at least one disorder, with 6 percent experiencing affective disorders, 7 percent having an anxiety disorder, and 5 percent having a diagnosis of substance abuse or dependence. In the Asian samples, rates of psychiatric disorders are lower (9 percent of males and 10 percent of females report any past year psychiatric disorder), but the degree of mental distress, as measured by the K10, is similar to what is experienced in the Latino samples.

All four samples consist of individuals who mainly are of working age (25 to 64 years old) because persons over 65 years old and students were excluded from the analysis. The 
largest ethnic group among the Latinos is the Mexican Americans; in the Asian samples, the largest ethnic group is Chinese Americans. In the Latino samples, about 42 percent of male and 43 percent of female respondents have less than a high school education (not shown in Table 1), and 59-78 percent of the Latino and Asian samples are immigrants. These characteristics are very different from those of other samples used to study psychiatric disorders and labor market outcomes. For example, in the NCS sample used by Ettner et al. (1997), only 13 percent of females and 16 percent of males had less than a high school education, and 6 to 7 percent were immigrants. Individuals who are foreign born and have less than a high school education are likely to face quite different job circumstances, and possibly different labor market consequences of mental illness, compared to American born, more educated workers.

\section{$5 \quad$ Results}

Tables 2-5 show estimation results from employment, weeks worked and work absence models for the four samples (Latino males, Latino females, Asian males, Asian females). In each table, Panel A shows results from three models where any current psychiatric disorder is the main covariate of interest. The first model is a standard probit model, the second model is a standard probit model with prior disorder included as a covariate, and the third model is either a bivariate probit model (in the case of a binary dependent variable), or a TSLS model (in the case of a continuous dependent variable). These models directly account for the possibility that the association between psychiatric disorders and labor market outcomes may be confounded by unobserved factors. Panel B in each table (Tables 2-5) shows the same set of model results from the analysis of the K10 mental distress score. 


\subsection{Main Findings for Latino Males and Females}

Among Latino males, the standard probit model suggests that having a psychiatric disorder in the past year is associated with a statistically significant, 10 percentage point reduction in the probability of being currently employed (about a 12 percent reduction at the sample mean employment rate of 81 percent) (Table 2, Panel A, Column 1). Including prior disorder as a covariate (Table 2, Panel A, Column 2) does not appreciably change the magnitude or statistical significance of this effect, and estimating mental health and employment equations simultaneously (Table 2, Panel A, Column 3) decreases the magnitude of the result to an 8 percentage point (about a 10 percent at the sample mean) reduction. The magnitude of this effect of psychiatric disorders on the probability of employment for Latino males is very similar to findings of Ettner et al. [9], who report an 11 percentage point reduction for men (about a 12 percent reduction at the sample mean employment rate of 91 percent) using the NCS sample.

Among employed Latino men, psychiatric disorders do not have a statistically significant association with the number of weeks worked in the past year (Table 2, Panel A, Columns 4-6). This also is the case when the TSLS method is used to account for the potential endogeneity of psychiatric disorders (Table 2, Panel A, Column 6), and when broad disorder classes are considered separately (results not shown). Having a recent psychiatric disorder, however, does appear to increase the probability of having at least one work absence in the past month among employed Latino men (Table 2, Panel A, Columns 7-9). The magnitude of this effect ranges from 15 to 19 percentage points (an increase of 60 to 76 percent at the sample mean of 25 percent), depending on the model specification. Although the effect loses statistical significance in the bivariate probit model, the estimated rho in this model is close to zero and statistically 
insignificant at the 0.05 level, suggesting that estimating the mental health and labor market equations jointly is not advantageous.

Thus far, this analysis focuses on estimating the association between DSM IV psychiatric diagnoses, as measured through diagnostic interviews, and labor market outcomes among Latino men. Diagnostic interviews have become standard tools in psychiatric epidemiology [53], and allow us to compare results with other analyses that have used the same measures. The measures used up to this point, however, are dummy variables, indicating whether or not the respondent meets the threshold for diagnosis, and are not informative in providing information about the severity of the condition. For this reason, we also consider the effects of the severity of symptoms on labor market outcomes using the K10 measure, which is a continuous scale of nonspecific psychological distress. We use the same approach as before and estimate models with and without prior psychiatric disorder. Because we have a binary outcome (such as employment) and a continuous outcome (the K10 measure), we use TSLS methods for all models and estimate linear probability models in cases where the dependent variable is binary.

Panel B of Table 2 shows that for Latino males, higher K10 score is associated with statistically significant, lower probability of being employed and statistically significant, higher probability of having a work absence in the past month. The TSLS results are consistent in sign with the OLS findings, but they lose statistical significance at conventional levels. The identifying instruments performed well -- they were good predictors of the K10 score, and passed the overidentification test.

Findings for Latino females were similar to those of Latino males, but the effects for females are larger in magnitude and more robust across the models relative to the male findings (Table 3). Having a recent psychiatric disorder is associated with a 23 percentage point 
reduction in the probability of being employed (this reduction translates into a 41 percent reduction at the sample mean employment rate of 56 percent). The effect remains large and statistically significant in the bivariate probit model (Table 3, Panel A, Column 3). The size of this effect is larger than what Ettner et al. [9] report for women in the NCS - they find that psychiatric disorder is associated with an 11 percentage point, or about a 14 percent (at the sample mean), reduction in employment probability. Among employed Latino females, current disorder also is associated with an increased probability of reporting at least one work absence in the past month. While this effect is marginally statistically significant in some cases, having a disorder appears to appreciably increase the probability of work absence - the size of this effect is 13-18 percentage points, about a 48-67 percent increase at the sample mean absence rate of 27 percent.

As seen for Latino males, higher levels of mental distress among Latino females, as measured by the K10, are associated with statistically significant, adverse effects on the probability of employment and work absences in the past month (Table 3, Panel B). These effects persist across models, although they lose some statistical significance in the TSLS models (Table 2, Panel B, Columns 3 and 9). Like Latino males, Latino females with current psychiatric disorders do not appear to work fewer weeks than similar individuals who do not meet diagnostic criteria for current disorders.

\subsection{Main Findings for Asian Males and Females}

Among Asian males, having a current psychiatric disorder is associated with a 13 percentage point reduction in the probability of employment, which is a 15 percent reduction at the sample mean of 84 percent (Table 3, Panel A, Column 1). The magnitude of this effect is similar to the 12 percent reductions we find for Latino males and the sample of mostly white, 
native born, NCS males used by Ettner et al. This effect, however, is less robust for Asian males that it was for Latino males. Including the prior psychiatric disorder covariate (Table 3, Panel A, Column 2), and explicitly modeling correlation between unobserved factors using the bivariate probit model (Table 3, Panel A, Column 3), reduce the size and statistical significance of the effect.

Similarly, in the work absence models (Table 3, Panel A, Columns 7-9), having a current psychiatric disorder is associated with a small, statistically insignificant increase in the probability of having an absence. This effect does not persist when prior psychiatric disorder is included as a covariate, or when the bivariate probit model is used to model correlation between unobserved factors. In Panel B of Table 3, we see that higher levels of mental distress are associated with some detrimental effects on employment and labor supply. These effects, however, are small and not statistically significant in many cases.

In Table 5, we find an even more inconsistent pattern for Asian females. The measure of any psychiatric disorder has a negative, but statistically insignificant association with the probability of being employed and the number of weeks worked (Table 5, Panel A, Columns 16). There is a positive association but not statistically significant association between psychiatric disorders and absences (Table 5, Panel A, Columns 7-9). Panel B of Table 5 shows suggestive but small and statistically insignificant effects of mental distress on labor market outcomes for Asian females. In sum, these results for Asian females are consistent with the results found for Asian males, but not consistent with those for Latino females, which showed that psychiatric disorders detract significantly from labor market outcomes. 


\subsection{Further Analyses and Sensitivity Checks}

For brevity, we discuss in the text but do not show results from some sensitivity analyses including: analyses of specific disorder classes; analyses in which the out of labor force respondents are considered as a separate category; and findings from statistical tests related to TSLS and bivariate probit estimation.

\subsubsection{Considering out of labor force as a separate outcome}

In our analysis of employment, we initially ignored the distinction between respondents who reported they were out of the labor force, and respondents who stated they were unemployed. Both of these categories were combined as the baseline category. To gauge whether separating these groups affects our interpretation of the results, we experimented with multinomial logit models, which allow for a polychotomous outcome and are estimated using maximum likelihood. This model distinguishes respondents who are unemployed and looking for work from respondents who are out of the labor force. The out of labor force category includes some early retirees and disabled individuals, but it mostly includes individuals who were not looking for a job and did not work at all in the past 52 weeks for unspecified reasons. We focus on Latino males, Latino females, and Asian females -- the three samples in which we found statistically significant effects of psychiatric disorders and mental distress on labor market outcomes in the main analysis.

For Latino males and females, we find that having a psychiatric disorder has larger and more robust effects on being out of the labor force than on being unemployed, but mental distress has similar effects on both the unemployment and out of labor force outcomes. Among Asian males, the opposite is true - we see that having a psychiatric disorder increases the probability of unemployment, and not being out of the labor force. For Asian males, however, 
mental distress is associated with being out of the labor force rather than unemployment. Our data are not detailed enough for a comprehensive analysis of this issue, since we only know the exact reason for being out of the labor force for a sub-set of respondents. However, it does suggest that among Latinos, psychiatric disorders are associated with leaving the labor force entirely rather than a temporary bout of unemployment, while for Asian males, the opposite is true.

\subsubsection{Effects of specific disorder classes}

As another sensitivity check, we estimated models of employment, labor supply and absenteeism where dummy indicators for current affective disorders, current anxiety disorders, and current substance use disorders were considered separately, instead of using a dummy indicator of any current mental disorder. We also estimated the multinomial logit models with these specific disorder classes as covariates. In general, the effects of these broad diagnostic groups were consistent with the main findings, although in some cases we lose precision. Again, we focus on Latino males and females and Asian males, since we did not find evidence in the main analysis of detrimental effects of mental disorders for Asian females.

Affective disorders appear to be more debilitating to labor market outcomes than anxiety disorders, particularly for males. The findings indicate: (1) affective disorders are associated with lower probability of being employed in all three samples; and (2) affective disorders are associated with being out of the labor force, and not with temporary unemployment, for Latino males and females. Anxiety disorders have less consistent effects across the samples. Among Latino males and females, anxiety disorders are associated with being out of the labor force; however, this effect is not evident for Asian males, and anxiety disorders are associated with work absences only in the Latino female sample. In the case of substance use disorders, this 
disorder class was associated with being out of the labor force for Latino males and females, and was associated with being unemployed for Asian males.

\subsubsection{Empirical performance of identifying variables}

In all but 1 of the 8 bivariate probit models estimated, the estimated correlation between the error terms in the labor market outcome and psychiatric disorder equations was not statistically significant at conventional levels. This finding suggests that in general there is no advantage of the bivariate probit model over the standard probit model in this analysis. We note that this conclusion hinges on the validity of the identifying assumptions made. As an informal test, we re-estimated bivariate probit models of employment that included the three identifying variables (number of early disorders, religious support, religious frequency) in both the psychiatric disorder and labor market equations. The religious frequency and support variables were statistically significant (at the 0.05 level) predictors of labor market outcomes in the Latino female model for absenteeism, which reduces confidence in our identification strategy in this case. However, using only the number of early disorders variable to identify the model (and including the two religion variables in the employment equation) yielded very similar results.

In the TSLS models, the identifying variables perform moderately well in terms of predictive power. In all but two models, in which the F statistic was 6 and 8 respectively, the $\mathrm{F}$ statistic on the identifying variables ranged from 9 to 88 . The identifying variables passed the over-identification test at the 0.05 level in all but two cases. In these models, however, the identifying restrictions passed the over-identification test when the religion variables were not used as identifying instruments, and the findings were insensitive to this modification. 


\section{Conclusions}

This paper examines the labor market consequences of psychiatric disorders in a population that has not been studied to date - ethnic minorities of Latino and Asian descent, most of whom are immigrants. As these demographic groups become a larger portion of the workforce, much more research is needed on their labor market experiences. The availability of the NLAAS, which measures psychiatric disorders and labor market outcomes in a national sample of Latino and Asian Americans, allows us to study the labor market consequences of mental illness in these demographic groups for the first time.

In this study, we find somewhat different results for Latinos and Asians. Psychiatric disorders and mental distress have appreciable, negative associations with the probability of being employed, and large, positive associations with work absences for Latino males and females. While mental distress impacts both unemployment and being out of the labor force among Latinos, meeting diagnostic criteria for a disorder is associated with being out of the labor force, rather than being unemployed. As a whole, the findings indicate that mental illness imposes labor market costs on Latinos that are at least as large and as important as those found in studies based on mostly white samples. The similarity between NLAAS Latino and NCS males [9] in the effects of psychiatric disorder on employment (12 percent reductions for both NCS males and NLAAS Latino males) is striking, given the large differences in education, immigrant status, English language proficiency and occupation.

The effect of having a recent psychiatric disorder is associated with a 15 percent reduction in the probability of employment for Asian males, which again is similar to what we find for Latino males and what previous researchers have reported for NCS males. However, particularly among female respondents, having a recent psychiatric disorder and symptoms of 
mental distress appear to have smaller and less consistent impacts on labor market outcomes for Asians compared to Latinos. This differential effect of psychiatric disorders on employment outcomes between Latinos and Asians might be linked to differential coping resources afforded by greater education. Compared to Latinos, Asian Americans in NLAAS are 1.8 times more likely to have a college degree, which may facilitate maintaining productivity and decreased likelihood of disability, even in the presence of psychiatric disorders. Another potential explanation for the limited effect of psychiatric illness on employment outcomes in Asians could be their higher proportion working in professional and managerial occupations (45.2 percent) than Latinos (16.8 percent) [54], with more discretion to be less productive or unproductive rather than take a sick day. A third possibility is cultural differences between Latinos and Asians in their reactions to mental illness. Asians have been found to show lower levels of absenteeism that has been explained as due to internalization of Confucianism upon work values [55]. There is some evidence that Asians are less likely than individuals from majority groups to endorse illness, stress, and depression as legitimate reasons for absence [56]. These work values may possibly restrain Asians with mental disorders from missing work, for stigma of being labeled as mentally ill by their employers or coworkers.

A primary limitation of this study is we cannot definitively address the potential endogeneity of psychiatric disorders. Although we attempt to do so using bivariate probit and TSLS models, our identification strategy is difficult to defend theoretically and does not perform well empirically for Latino females. Thus, we emphasize our standard results, stressing that our rich data source substantially reduces the possibility of unobserved confounding variables. The NLAAS was designed specifically to capture the most important determinants of mental disorders for Latino and Asian populations. In particular, we are able to control both prior 
mental illness and for comorbid physical health conditions, both of which were likely to be important confounding variables in this analysis.

Our results suggest that there may be important labor market benefits associated with public health policies targeted at the prevention and effective treatment of mental illnesses in ethnic minority groups. In the US, there is ample evidence of health care disparities, or unequal treatment of patients based on race and ethnicity that is not related to need for services or patient preferences [57]. Wells et al. [58], for example, find that that despite similar levels of psychiatric need between Latinos and non-Latinos, Latinos were much more likely than nonLatinos to report not receiving mental health services (26 percent versus 12 percent). Our findings suggest that eliminating these kinds of disparities and expanding access to services may have significant labor market benefits - not just for majority populations, as has been demonstrated, but also for Asian and Latino Americans. We recommend that future research continue to focus on these demographic groups and as well as other under-studied and underserved populations in order to fully understand the labor market benefits of preventing and treating mental illness. 


\section{References}

1. Harnois, G. \& Gabriel, P. 2002. Mental health and work: Impact, issues, and good practices. World Health Organization and International Labor Organization, Accessed on-line at www.who.int/mental_health/media/en/712.pdf\#search='policy\%20and\%20workplace\%2 0and\%20mental\%20illness, 10/3/05.

2. WHO World Mental Health Survey Consortium. Prevalence, severity, and unmet need for treatment of mental disorders in the World Health Organization World Mental Health Surveys. Journal of the American Medical Association 2004; 291(21): 2581-2590.

3. Murray, C.J.L., and A.D. Lopez, eds. 1996. The global burden of disease and injury series, volume 1: a comprehensive assessment of mortality and disability from diseases, injuries, and risk factors in 1990 and projected to 2020. Cambridge, MA: Harvard School of Public Health on behalf of the World Health Organization and the World Bank, Harvard University Press.

4. National Institute of Mental Health (NIMH). The economic cost of mental illness, 1992. The Lewin Group, 2000.

5. Marcotte, D.E. and Wilcox-Gok, V. Estimating the employment and earnings costs of mental illness: recent developments in the United States. Social Science \& Medicine 2001; 53: 21-27.

6. Alexandre, P.K. and French, M.T. Labor supply of poor residents in metropolitan Miami, Florida: The role of depression and the co-morbid effects of substance use. The Journal of Mental Health Policy and Economics 2001; 4: 161-173.

7. Kessler, R.C. and Frank, R.G. The impact of psychiatric disorders on work loss days. Psychological Medicine 1997; 27: 861-873.

8. Frank, R. and Gertler, P. As assessment of measurement error bias for estimating the effect of mental distress on income. The Journal of Human Resources 1991; 26: 154-164.

9. Ettner, S.L., Frank, R.G., and Kessler, R.C. The impact of psychiatric disorders on labor market outcomes. Industrial and Labor Relations Review 1997; 51: 64-81.

10. Berndt, E.R., Finkelstein S.N., Greenberg, P.E., Howland, R.H., Keith, A., Rush, A.J., Russell, J., and Keller, M.B. Workplace performance effects from chronic depression and its treatment. Journal of Health Economics 1998; 17: 511-535. 
11. Kouzis, A.C. and Eaton, W.W. Emotional disability days: Prevalence and predictors. American Journal of Public Health 1994; 84: 1304-1307.

12. Kessler, R.C., Barber C., Birnbaum, H.G., Frank, R.G., Greenberg, P.E., Rose, R.M., Simon, G.E., and Wang, P. Depression in the workplace: Effects on short-term disability. Health Affairs 1999; 5: 163-171.

13. Kessler, R.C. The National Comorbidity Survey of the United States. International Review of Psychiatry 1994; 6: 365-376.

14. Fullerton, H.N. and Toossi, M. Labor force projections to 2010: steady growth and changing composition. Monthly Labor Review November 2001: 21-38.

15. Migration Policy Institute, The foreign born in the US labor force: Numbers and trends. Accessed at www.migrationpolicy.org/ foreignborninuslaborforce.pdf, November 1, 2004.

16. Alegria, M., Takeuchi, D., Canino, G., Duan, N., Shrout, P., Meng, X., et al. (2004). "Considering context, place and culture: the National Latino and Asian American study." International Journal of Methods in Psychiatric Research 13(4): 208-20.

17. US Census Bureau, Census Bureau projects tripling of Hispanic and Asian populations in 50 years: non-Hispanic whites may drop to half of total population. Accessed at http://www.census.gov/Press-Release/www/releases/archives/population/001720.html on 9/1/2004.

18. Kossoudiji, S.A. English language ability and the labor market opportunities of Hispanic and East Asian immigrant men. Journal of Labor Economics 1988; 6: 205-228.

19. Bureau of Labor Statistics. Employed persons by occupation, race, Hispanic or Latino ethnicity, and sex, http://stats.bls.gov/cps/cpsaat10.pdf, accessed 10/04.

20. Bureau of Labor Statistics. Employed persons by detailed occupation, sex, race, and Hispanic or Latino ethnicity, http://stats.bls.gov/cps/cpsaat11.pdf, accessed 10/04.

21. Mason, P.L. Race, culture, and skill: Interracial wage differences among AfricanAmericans, Latinos and Whites. Review of Black Political Economy 1997; 25: 5-39.

22. Becker, G.S. Human capital and the personal distribution of income: an analytical approach. Ann Arbor, MI: University of Michigan 1967. 
23. Ben-Porath, Y. The production of human capital and the life cycle of earnings. Journal of Political Economy 1967; 75: 353-367.

24. Mincer, J. Schooling, experience, and earnings. New York: Columbia University Press for the National Bureau of Economic Research 1974.

25. Mulahy, J and Sindelar, J. Life-cycle effects of alcoholism on education, earnings, and occupation. Inquiry 1989; 26: 272-82.

26. U.S. Surgeon General. Mental Health: a report of the Surgeon General. Washington DC: Health and Human Services Department 1999.

27. Bjorklund, A. Unemployment and mental health: some evidence from panel data. Journal of Human Resources 1985; 20: 469-483.

28. Greene, W.H. Econometric Analysis, Fifth Edition. Upper Saddle River, NJ: Pearson Education Inc. 2003.

29. Dewa, C.S. and Lin, E. Chronic physical illness, psychiatric disorder and disability in the workplace. Social Science \& Medicine 2000; 51: 41-50.

30. McDonald, Z. and Shields, M.A. Does drinking affect employment? Evidence from England. Health Economics 2004; 13: 139-155.

31. Evans, W.N., Schwab R.M., 1995, Finishing high school and starting college: Do catholic schools make a difference. The Quarterly Journal of Economics 110, 941-974.

32. Goldman, D.P. et al., 2001, Effect of Insurance on Mortality in an HIV-Positive Population in Care. Journal of the American Statistical Association 96, 883-894.

33. Bound, J., Jaeger, D.A., and Baker, R.M. Problems with instrumental variables estimation when the correlation between the instruments and the endogenous explanatory variables is weak. Journal of the American Statistical Association. 1995; 90: 443-450.

34. Bollen, K.A., Guilkey, D.K., and Mroz, T.A. Binary outcomes and endogenous explanatory variables: tests and solutions with an application to the demand for contraceptive use in Tunisia. Demography 1995; 32: 111-131.

35. Nelson, C.R. and Startz, R. The distribution of the instrumental variables estimator and its T-Statistic when the instrument is a poor one. Journal of Business 1990; 63: S125S139. 
36. Staiger, D. and Stock, J.H. Instrumental variables regression with weak instruments. Econometrica 1997; 65: 557-86.

37. Rashad, I. and Kaestner, R. Teenage sex, drugs and alcohol use: Problems identifying the cause of risky behaviors. Journal of Health Economics 2004; 3: 493-503.

38. Mullahy, J. and Sindelar, J. Employment, unemployment, and problem drinking. Journal of Health Economics 1996; 15: 409-434.

39. McCulloch, A. Social environments and health: a cross sectional survey. British Medical Journal 2001; 323: 208-209.

40. Heien, D. Do drinkers earn less. Southern Economic Journal 1996; 63: 60-8.

41. Hamilton, V. and Hamilton, B. Alcohol and earnings: Does drinking yield a wage premium? Canadian Journal of Economics 1997; 30: 135-151.

42. Hamilton, V., Merrigan, P., and Dufresne, E. Down and out: estimating the relationship between mental health and unemployment. Health Economics 1997; 6: 397-406.

43. Barret, G.F. The effect of alcohol consumption on earnings. Economic Record 2002; 78(1): 79-96.

44. DeSimone, J. Illegal drug use and employment. Journal of Labor Economics 2002; 20: 952-977.

45. McKenzie, K., Whitley, R., and Weich, S. Social capital and mental health. The British Journal of Psychiatry 2002; 181: 280-283

46. Boydell, J., McKenzie, K., van Os, J., et al. The social causes of schizophrenia: an investigation into the influence of social cohesion and social hostility. Schizophrenia Research 2002; 53: 264.

47. Rose, R. How much does social capital add to individual health? A survey study of Russians. Social Science and Medicine 2000; 51: 1421-1435.

48. Weitzman, E. R. and Kawachi, I. Giving means receiving: the protective effect of social capital on binge drinking on college campuses. American Journal of Public Health 2000; 90: 1936-1939. 
49. Heeringa, S., Wagner, J., Torres, M., Duan, N., Adams, T., and Berglund, P. Sample designs and sampling methods for the Collaborative Psychiatric Epidemiology Studies (CPES). In press.

50. Semler, G., Von Cranach, M., and Wittchen, E. Comparisons between the Composite International Diagnostic Interview and the present state examination. Geneva, Switzerland: Report to the WHO/ADAMHA Task Force on Instrument Development, 1987.

51. Wittchen, H.U. Reliability and validity studies of the WHO - Composite International Diagnostic Interview (CIDI): A critical review. Psychiatry Research 1994; 28: 57-84.

52. World Health Organization. Disability Assessment Schedule II (WHO-DAS II) Geneva: World Health Organization, 1998.

53. Kessler, R.C., Andrews, G., Colpe, L.J., Hiripi, E., Mroczek, D.K., Normand, S.-L.T., et al.. Short screening scales to monitor population prevalences and trends in non-specific psychological distress. Psychological Medicine 2002; 32(6): 959-976.

54. United States Bureau of Labor Statistics. Employed Persons by occupation, race, Hispanic or Latino ethnicity, and sex. Washington, DC 2004.

55. Kuzmits, F.E. Differences in incidences of absenteeism and discipline between Vietnamese and non-Vietnamese employees. International Journal of Organizational Analysis 1995; 3(3): 303-313.

56. Johns, G. \& Xie, J. L. Perceptions of absence from work: People's Republic of China versus Canada. Journal of Applied Psychology 1998; 83(4): 515-530.

57. Institute of Medicine. Unequal Treatment: Confronting racial and ethnic disparities in health care Washington: D.C.: The National Academies Press, 2002.

58. Wells, K., Klap, R., Koike, A., \& Sherbourne, C.. Ethnic disparities in unmet need for alcoholism, drug abuse and mental health care. The American Journal of Psychiatry 2001; 158(12): 2027-2032. 
Table 1: Weighted Means and Standard Errors

\begin{tabular}{|c|c|c|c|c|c|}
\hline Variable & Definition & $\begin{array}{c}\text { Latino } \\
\text { Males } \\
(\mathrm{n}=1,016)\end{array}$ & $\begin{array}{c}\text { Asian } \\
\text { Males } \\
(\mathrm{n}=864)\end{array}$ & $\begin{array}{c}\text { Latino } \\
\text { Females } \\
(\mathrm{n}=1,212)\end{array}$ & $\begin{array}{c}\text { Asian } \\
\text { Females } \\
(\mathrm{n}=954)\end{array}$ \\
\hline \multicolumn{6}{|c|}{ Labor Market Outcomes } \\
\hline Employed & $\begin{array}{c}\text { Dummy variable }=1 \text { if } \\
\text { respondent is employed } \\
\text { part-time or full-time, } 0 \\
\text { otherwise }\end{array}$ & $\begin{array}{c}0.806 \\
(0.019)\end{array}$ & $\begin{array}{c}0.837 \\
(0.014)\end{array}$ & $\begin{array}{c}0.564 \\
(0.022)\end{array}$ & $\begin{array}{c}0.639 \\
(0.023)\end{array}$ \\
\hline $\begin{array}{l}\text { Out of labor } \\
\text { force }\end{array}$ & $\begin{array}{l}\text { Dummy variable }=1 \text { if } \\
\text { respondent is retired, } \\
\text { disabled, a homemaker, } \\
\text { or otherwise not } \\
\text { employed and not } \\
\text { looking for work, } 0 \\
\text { otherwise }\end{array}$ & $\begin{array}{c}0.116 \\
(0.014)\end{array}$ & $\begin{array}{c}0.111 \\
(0.012)\end{array}$ & $\begin{array}{c}0.355 \\
(0.021)\end{array}$ & $\begin{array}{c}0.274 \\
(0.027)\end{array}$ \\
\hline Unemployed & $\begin{array}{l}\text { Dummy variable = } 1 \text { if } \\
\text { respondent is } \\
\text { unemployed or } \\
\text { temporarily laid off, } 0 \\
\text { otherwise }\end{array}$ & $\begin{array}{c}0.078 \\
(0.013)\end{array}$ & $\begin{array}{c}0.052 \\
(0.007)\end{array}$ & $\begin{array}{c}0.081 \\
(0.008)\end{array}$ & $\begin{array}{c}0.086 \\
(0.013)\end{array}$ \\
\hline Weeks worked & $\begin{array}{l}\text { Number of weeks that } \\
\text { respondent worked in } \\
\text { past year (among } \\
\text { employed respondents) }\end{array}$ & $\begin{array}{c}49.84 \\
(0.282)\end{array}$ & $\begin{array}{c}49.89 \\
(0.381)\end{array}$ & $\begin{array}{l}47.35 \\
(0.617)\end{array}$ & $\begin{array}{c}49.01 \\
(0.324)\end{array}$ \\
\hline $\begin{array}{l}\text { Absent in past } \\
\text { month }\end{array}$ & $\begin{array}{l}\text { Dummy variable }=1 \text { if } \\
\text { respondent missed at } \\
\text { least } 1 \text { full day of work in } \\
\text { the past } 30 \text { days (among } \\
\text { employed respondents), } 0 \\
\text { otherwise }\end{array}$ & $\begin{array}{c}0.252 \\
(0.018)\end{array}$ & $\begin{array}{c}0.196 \\
(0.018)\end{array}$ & $\begin{array}{c}0.264 \\
(0.019)\end{array}$ & $\begin{array}{c}0.274 \\
(0.022)\end{array}$ \\
\hline \multicolumn{6}{|c|}{$\underline{\text { Psychiatric disorders }}$} \\
\hline $\begin{array}{l}\text { Any current } \\
\text { psychiatric } \\
\text { disorder }\end{array}$ & $\begin{array}{l}\text { Dummy variable }=1 \text { if } \\
\text { respondent has diagnosis } \\
\text { of any } 12 \text { month } \\
\text { psychiatric disorder, } 0\end{array}$ & $\begin{array}{c}0.137 \\
(0.015)\end{array}$ & $\begin{array}{c}0.090 \\
(0.015)\end{array}$ & $\begin{array}{c}0.172 \\
(0.012)\end{array}$ & $\begin{array}{c}0.102 \\
(0.010)\end{array}$ \\
\hline
\end{tabular}


otherwise

\begin{tabular}{|c|c|c|c|c|c|}
\hline $\begin{array}{l}\text { Any current } \\
\text { affective disorder }\end{array}$ & $\begin{array}{l}\text { Dummy variable }=1 \text { if } \\
\text { respondent has diagnosis } \\
\text { of any affective disorder } \\
\text { (major depression or } \\
\text { dysthymia) in past } 12 \\
\text { months, } 0 \text { otherwise }\end{array}$ & $\begin{array}{c}0.058 \\
(0.010)\end{array}$ & $\begin{array}{c}0.044 \\
(0.010)\end{array}$ & $\begin{array}{c}0.093 \\
(0.007)\end{array}$ & $\begin{array}{c}0.056 \\
(0.009)\end{array}$ \\
\hline $\begin{array}{l}\text { Any current } \\
\text { anxiety disorder }\end{array}$ & $\begin{array}{l}\text { Dummy variable }=1 \text { if } \\
\text { respondent has diagnosis } \\
\text { of any anxiety disorder } \\
\text { (agoraphobia, social } \\
\text { phobia, generalized } \\
\text { anxiety disorder, panic } \\
\text { disorder) in past } 12 \\
\text { months, } 0 \text { otherwise }\end{array}$ & $\begin{array}{c}0.071 \\
(0.009)\end{array}$ & $\begin{array}{c}0.051 \\
(0.014)\end{array}$ & $\begin{array}{c}0.119 \\
(0.009)\end{array}$ & $\begin{array}{c}0.067 \\
(0.009)\end{array}$ \\
\hline $\begin{array}{l}\text { Any current } \\
\text { substance use } \\
\text { disorder }\end{array}$ & $\begin{array}{l}\text { Dummy variable }=1 \text { if } \\
\text { respondent has diagnosis } \\
\text { of any substance use } \\
\text { disorder (alcohol abuse } \\
\text { or dependence, drug } \\
\text { abuse or dependence) in } \\
\text { past } 12 \text { months, } 0 \\
\text { otherwise }\end{array}$ & $\begin{array}{c}0.046 \\
(0.007)\end{array}$ & $\begin{array}{c}0.022 \\
(0.007)\end{array}$ & $\begin{array}{c}0.013 \\
(0.005)\end{array}$ & $\begin{array}{c}0.010 \\
(0.002)\end{array}$ \\
\hline K10 score & $\begin{array}{l}\text { Score on the K10, a } 10 \\
\text { question screening scale } \\
\text { of psychiatric distress }\end{array}$ & $\begin{array}{c}12.96 \\
(0.190)\end{array}$ & $\begin{array}{c}12.97 \\
(0.257)\end{array}$ & $\begin{array}{c}14.67 \\
(0.288)\end{array}$ & $\begin{array}{c}13.61 \\
(0.168)\end{array}$ \\
\hline $\begin{array}{l}\text { Any prior } \\
\text { disorder }\end{array}$ & $\begin{array}{l}\text { Dummy variable }=1 \text { if } \\
\text { respondent had any } \\
\text { psychiatric disorder } \\
\text { before the past } 12 \text { months } \\
\text { (does not include } \\
\text { disorders in past } 12 \\
\text { months), } 0 \text { otherwise } \\
\text { Chronic Phy }\end{array}$ & $\begin{array}{c}0.207 \\
(0.019)\end{array}$ & $\begin{array}{c}0.120 \\
(0.017)\end{array}$ & $\begin{array}{c}0.175 \\
(0.012)\end{array}$ & $\begin{array}{c}0.105 \\
(0.017)\end{array}$ \\
\hline Asthma & $\begin{array}{l}\text { Dummy variable }=1 \text { if } \\
\text { respondent had asthma in } \\
\text { prior, } 0 \text { otherwise }\end{array}$ & $\begin{array}{c}0.068 \\
(0.014)\end{array}$ & $\begin{array}{c}0.069 \\
(0.009)\end{array}$ & $\begin{array}{c}0.110 \\
(0.013)\end{array}$ & $\begin{array}{c}0.085 \\
(0.012)\end{array}$ \\
\hline Diabetes & $\begin{array}{l}\text { Dummy variable }=1 \text { if } \\
\text { respondent had diabetes } \\
\text { in prior, } 0 \text { otherwise }\end{array}$ & $\begin{array}{c}0.056 \\
(0.007)\end{array}$ & $\begin{array}{c}0.041 \\
(0.005)\end{array}$ & $\begin{array}{c}0.073 \\
(0.007)\end{array}$ & $\begin{array}{c}0.056 \\
(0.011)\end{array}$ \\
\hline
\end{tabular}




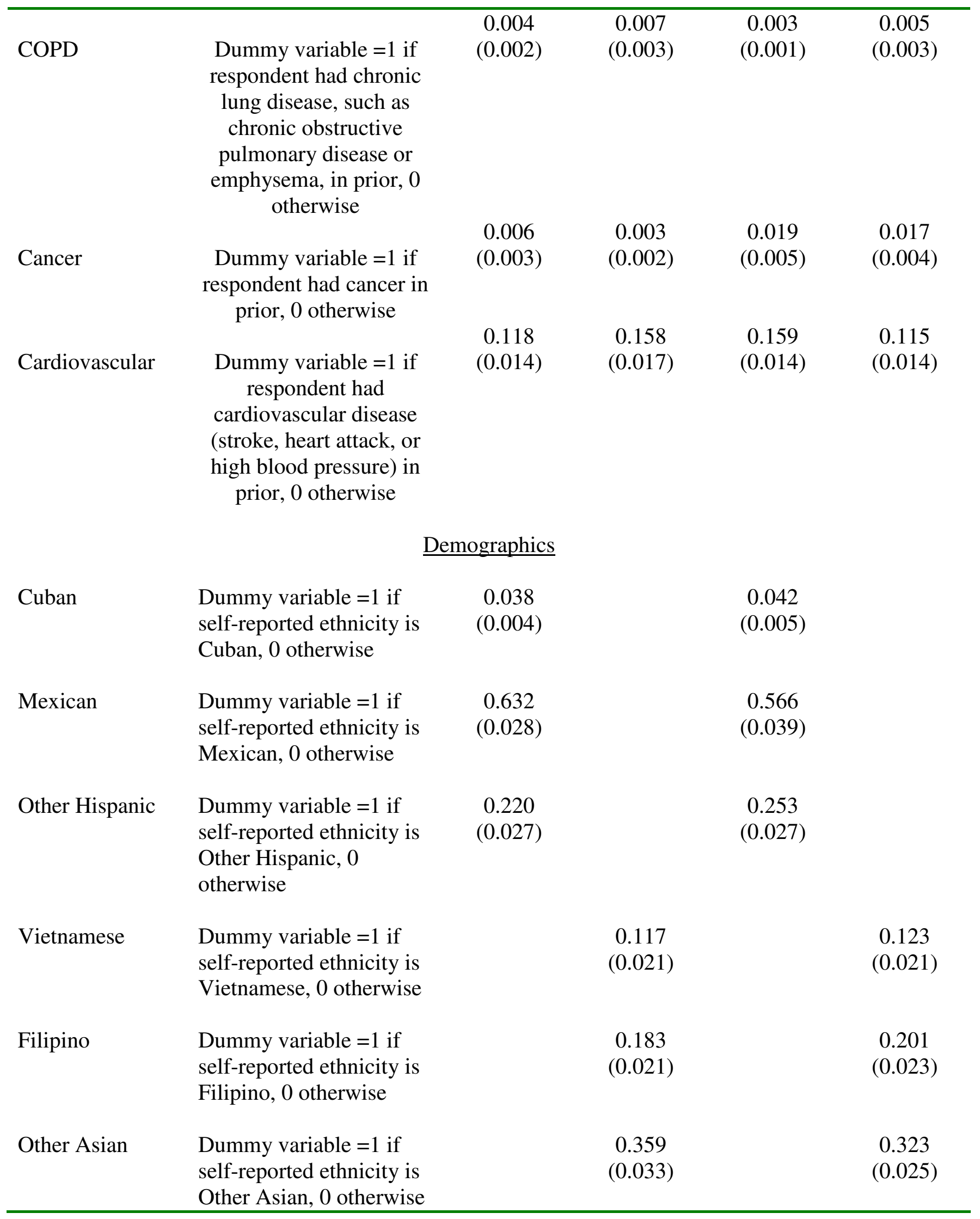




\begin{tabular}{|c|c|c|c|c|c|}
\hline $\begin{array}{l}\text { Number of } \\
\text { family members } \\
\text { under age } 18\end{array}$ & $\begin{array}{l}\text { Number of family } \\
\text { members under age } 18\end{array}$ & $\begin{array}{c}0.880 \\
(0.072)\end{array}$ & $\begin{array}{c}0.572 \\
(0.065)\end{array}$ & $\begin{array}{c}1.18 \\
(0.058)\end{array}$ & $\begin{array}{c}0.726 \\
(0.061)\end{array}$ \\
\hline Citizen & $\begin{array}{l}\text { Dummy variable = } 1 \text { if } \\
\text { respondent is a US } \\
\text { citizen, } 0 \text { otherwise }\end{array}$ & $\begin{array}{c}0.590 \\
(0.023)\end{array}$ & $\begin{array}{c}0.676 \\
(0.032)\end{array}$ & $\begin{array}{c}0.594 \\
(0.029)\end{array}$ & $\begin{array}{c}0.684 \\
(0.029)\end{array}$ \\
\hline Immigrant & $\begin{array}{l}\text { Dummy variable = } 1 \text { if } \\
\text { respondent is an } \\
\text { immigrant to the US, } 0 \\
\text { otherwise }\end{array}$ & $\begin{array}{c}0.591 \\
(0.025)\end{array}$ & $\begin{array}{c}0.755 \\
(0.027)\end{array}$ & $\begin{array}{c}0.587 \\
(0.029)\end{array}$ & $\begin{array}{c}0.782 \\
(0.035)\end{array}$ \\
\hline $\begin{array}{l}\text { Poor English } \\
\text { proficiency }\end{array}$ & $\begin{array}{l}\text { Dummy variable }=1 \text { if } \\
\text { respondent reports poor } \\
\text { language proficiency in } \\
\text { English, } 0 \text { otherwise }\end{array}$ & $\begin{array}{c}0.478 \\
(0.028)\end{array}$ & $\begin{array}{c}0.275 \\
(0.025)\end{array}$ & $\begin{array}{c}0.483 \\
(0.031)\end{array}$ & $\begin{array}{c}0.356 \\
(0.024)\end{array}$ \\
\hline Age 55 to 64 & $\begin{array}{l}\text { Dummy variable }=1 \text { if } \\
\text { age } 55 \text { to } 64,0 \text { otherwise }\end{array}$ & $\begin{array}{c}0.063 \\
(0.009)\end{array}$ & $\begin{array}{c}0.110 \\
(0.014)\end{array}$ & $\begin{array}{c}0.082 \\
(0.008)\end{array}$ & $\begin{array}{c}0.103 \\
(0.013)\end{array}$ \\
\hline Age 45 to 54 & $\begin{array}{l}\text { Dummy variable }=1 \text { if } \\
\text { age } 45 \text { to } 54,0 \text { otherwise }\end{array}$ & $\begin{array}{c}0.147 \\
(0.017)\end{array}$ & $\begin{array}{c}0.207 \\
(0.013)\end{array}$ & $\begin{array}{c}0.174 \\
(0.012)\end{array}$ & $\begin{array}{c}0.233 \\
(0.015)\end{array}$ \\
\hline Age 35 to 44 & $\begin{array}{l}\text { Dummy variable }=1 \text { if } \\
\text { age } 35 \text { to } 44,0 \text { otherwise }\end{array}$ & $\begin{array}{c}0.244 \\
(0.015)\end{array}$ & $\begin{array}{c}0.265 \\
(0.023)\end{array}$ & $\begin{array}{c}0.245 \\
(0.016)\end{array}$ & $\begin{array}{c}0.262 \\
(0.023)\end{array}$ \\
\hline Age 25 to 34 & $\begin{array}{l}\text { Dummy variable }=1 \text { if } \\
\text { age } 25 \text { to } 34,0 \text { otherwise }\end{array}$ & $\begin{array}{c}0.319 \\
(0.014)\end{array}$ & $\begin{array}{c}0.286 \\
(0.021)\end{array}$ & $\begin{array}{c}0.304 \\
(0.014)\end{array}$ & $\begin{array}{c}0.272 \\
(0.020)\end{array}$ \\
\hline $\begin{array}{l}\text { High school } \\
\text { graduate }\end{array}$ & $\begin{array}{l}\text { Dummy variable }=1 \text { if } \\
\text { high school graduate, } 0 \\
\text { otherwise }\end{array}$ & $\begin{array}{c}0.263 \\
(0.014)\end{array}$ & $\begin{array}{c}0.184 \\
(0.022)\end{array}$ & $\begin{array}{c}0.245 \\
(0.010)\end{array}$ & $\begin{array}{c}0.161 \\
(0.015)\end{array}$ \\
\hline $\begin{array}{l}\text { At least some } \\
\text { college }\end{array}$ & $\begin{array}{l}\text { Dummy variable }=1 \text { if } \\
\text { college graduate, } 0 \\
\text { otherwise }\end{array}$ & $\begin{array}{c}0.262 \\
(0.020)\end{array}$ & $\begin{array}{c}0.438 \\
(0.028)\end{array}$ & $\begin{array}{c}0.288 \\
(0.019)\end{array}$ & $\begin{array}{c}0.514 \\
(0.023)\end{array}$ \\
\hline $\begin{array}{l}\text { Married/Cohabiti } \\
\text { ng }\end{array}$ & $\begin{array}{l}\text { Dummy variable }=1 \text { if } \\
\text { married or cohabiting, } 0 \\
\text { otherwise }\end{array}$ & $\begin{array}{c}0.699 \\
(0.015)\end{array}$ & $\begin{array}{c}0.703 \\
(0.027)\end{array}$ & $\begin{array}{c}0.628 \\
(0.019)\end{array}$ & $\begin{array}{c}0.729 \\
(0.021)\end{array}$ \\
\hline \multirow[t]{2}{*}{$\begin{array}{l}\text { Separated/ } \\
\text { Divorced/ } \\
\text { Widowed }\end{array}$} & $\begin{array}{l}\text { Dummy variable }=1 \text { if } \\
\text { separated/divorced/wido } \\
\text { wed, } 0 \text { otherwise }\end{array}$ & $\begin{array}{c}0.115 \\
(0.012)\end{array}$ & $\begin{array}{c}0.059 \\
(0.014)\end{array}$ & $\begin{array}{c}0.211 \\
(0.018)\end{array}$ & $\begin{array}{c}0.098 \\
(0.014)\end{array}$ \\
\hline & & 6.27 & 6.24 & 6.25 & 6.10 \\
\hline
\end{tabular}




\begin{tabular}{|c|c|c|c|c|c|}
\hline $\begin{array}{l}\text { Unemployment } \\
\text { rate }\end{array}$ & $\begin{array}{l}\text { State unemployment rate } \\
\text { in year of interview }\end{array}$ & $\begin{array}{l}(0.082) \\
\text { ng Varial }\end{array}$ & $(0.075)$ & $(0.076)$ & $(0.083)$ \\
\hline $\begin{array}{l}\text { Number of } \\
\text { psychiatric } \\
\text { disorders with } \\
\text { age of onset } \\
\text { before age } 18\end{array}$ & $\begin{array}{l}\text { Number of the following } \\
\text { illnesses with onset } \\
\text { before age 18: major } \\
\text { depression, dysthymia, } \\
\text { agoraphobia, alcohol or } \\
\text { drug abuse/dependence, } \\
\text { social phobia, } \\
\text { generalized anxiety } \\
\text { disorder, panic attack, } \\
\text { panic disorder, or post } \\
\text { traumatic stress disorder } \\
\text { anorexia/bulimia }\end{array}$ & $\begin{array}{c}0.326 \\
(0.037)\end{array}$ & $\begin{array}{c}0.220 \\
(0.050)\end{array}$ & $\begin{array}{c}0.340 \\
(0.027)\end{array}$ & $\begin{array}{c}0.206 \\
(0.031)\end{array}$ \\
\hline $\begin{array}{l}\text { Attends religious } \\
\text { services at least } \\
\text { weekly }\end{array}$ & $\begin{array}{l}\text { Dummy variable }=1 \text { if } \\
\text { respondent attends } \\
\text { religious services at least } \\
\text { once a week, } 0 \text { otherwise }\end{array}$ & $\begin{array}{c}0.232 \\
(0.021)\end{array}$ & $\begin{array}{c}0.277 \\
(0.026)\end{array}$ & $\begin{array}{c}0.366 \\
(0.022)\end{array}$ & $\begin{array}{c}0.313 \\
(0.021)\end{array}$ \\
\hline $\begin{array}{l}\text { Often uses } \\
\text { religious means } \\
\text { to deal with life's } \\
\text { problems }\end{array}$ & $\begin{array}{l}\text { Dummy variable }=1 \text { if } \\
\text { respondent often uses } \\
\text { religious or spiritual } \\
\text { means to deal with life's } \\
\text { problems (such as } \\
\text { praying, mediating etc.), } \\
0 \text { otherwise }\end{array}$ & $\begin{array}{c}0.214 \\
(0.017)\end{array}$ & $\begin{array}{c}0.207 \\
(0.022)\end{array}$ & $\begin{array}{c}0.392 \\
(0.019)\end{array}$ & $\begin{array}{c}0.330 \\
(0.023)\end{array}$ \\
\hline
\end{tabular}


Table 2 Effects of psychiatric disorders on labor market outcomes: Weighted regression results for Latino males

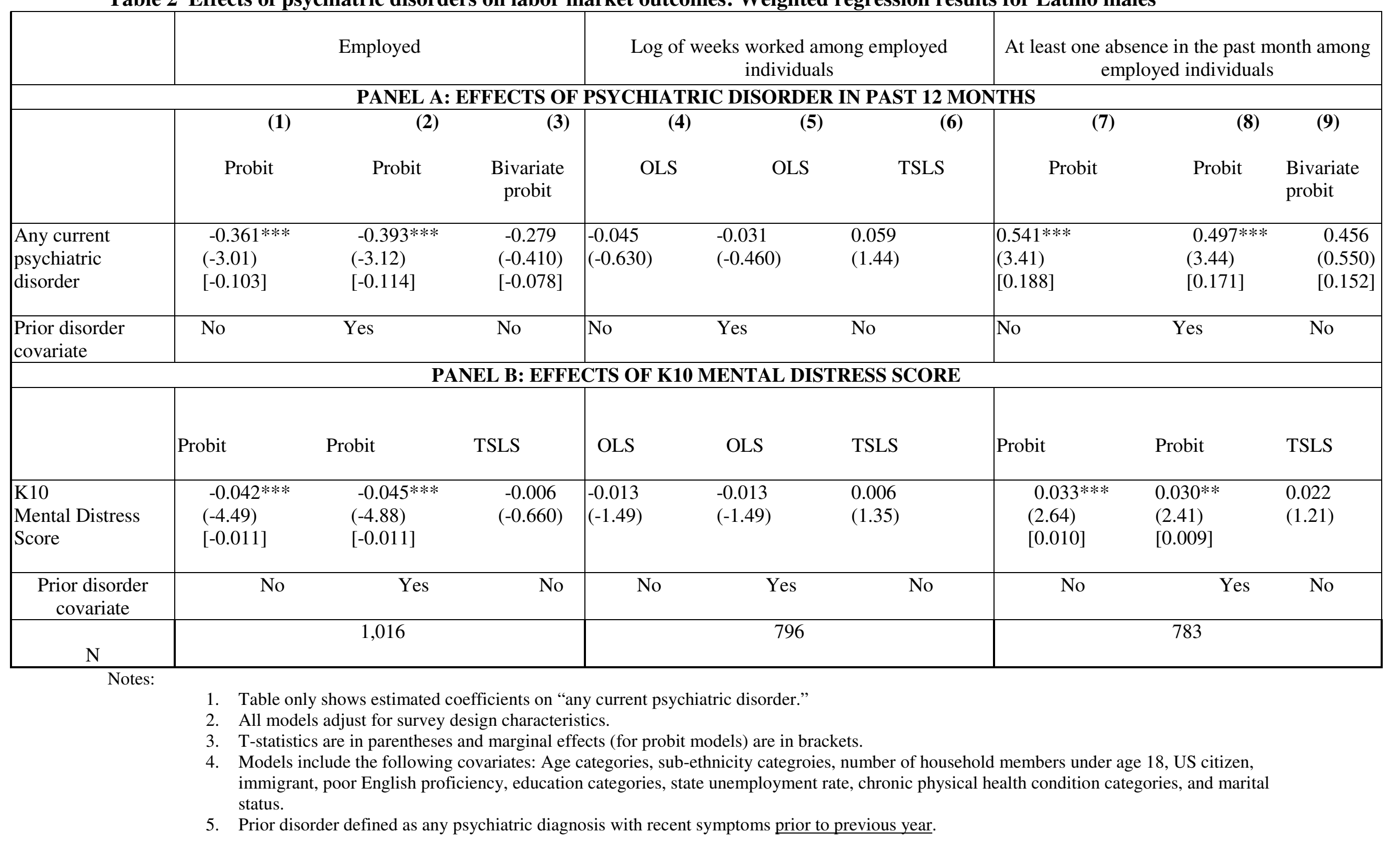


Table 3 Effects of psychiatric disorders on labor market outcomes: Weighted regression results for Latino females

\begin{tabular}{|c|c|c|c|c|c|c|c|c|}
\hline & \multicolumn{3}{|c|}{ Employed } & \multicolumn{2}{|c|}{$\begin{array}{c}\text { Log of weeks worked among employed } \\
\text { individuals }\end{array}$} & \multicolumn{3}{|c|}{$\begin{array}{c}\text { At least one absence in the past month among } \\
\text { employed individuals }\end{array}$} \\
\hline \multicolumn{9}{|c|}{ PANEL A: EFFECTS OF PSYCHIATRIC DISORDER IN PAST 12 MONTHS } \\
\hline & (1) & (2) & (3) & (4) & (6) & (7) & (8) & (9) \\
\hline & Probit & Probit & $\begin{array}{l}\text { Bivariate } \\
\text { probit }\end{array}$ & OLS & TSLS & Probit & Probit & Bivariate probit \\
\hline $\begin{array}{l}\text { Any current } \\
\text { psychiatric } \\
\text { disorder }\end{array}$ & $\begin{array}{l}-0.582 * * * \\
(-5.85) \\
{[-0.229]}\end{array}$ & $\begin{array}{l}-0.564 * * * \\
(-5.49) \\
{[-0.222]}\end{array}$ & $\begin{array}{l}-0.724 * * * \\
(-2.77) \\
{[-0.282]}\end{array}$ & $\begin{array}{l}0.094^{*} \\
(1.80)\end{array}$ & $\begin{array}{l}0.156 \\
(1.02)\end{array}$ & $\begin{array}{c}0.415^{*} \\
(1.86) \\
{[0.140]}\end{array}$ & $\begin{array}{l}0.396^{*} \\
(1.72) \\
{[0.134]}\end{array}$ & $\begin{array}{c}0.504 * \\
(1.78) \\
{[0.177]}\end{array}$ \\
\hline $\begin{array}{l}\text { Prior disorder } \\
\text { covariate }\end{array}$ & No & Yes & No & Yes & No & No & Yes & No \\
\hline \multicolumn{9}{|c|}{ PANEL B: EFFECTS OF K10 MENTAL DISTRESS SCORE } \\
\hline & Probit & Probit & TSLS & OLS & TSLS & Probit & Probit & TSLS \\
\hline $\begin{array}{c}\text { K10 } \\
\text { Mental Distress } \\
\text { Score }\end{array}$ & $\begin{array}{l}-0.028 * * * \\
(-3.03) \\
{[-0.011]}\end{array}$ & $\begin{array}{l}-0.028 * * * \\
(-3.05) \\
{[-0.011]}\end{array}$ & $\begin{array}{l}-0.016^{*} \\
(-1.79)\end{array}$ & $\begin{array}{c}0.004 \\
(0.900)\end{array}$ & $\begin{array}{l}0.017 \\
(1.26)\end{array}$ & $\begin{array}{c}0.055 * * * \\
(4.88) \\
{[0.016]}\end{array}$ & $\begin{array}{c}0.054 * * * \\
(4.81) \\
{[0.016]}\end{array}$ & $\begin{array}{l}0.031 * * * \\
(3.13)\end{array}$ \\
\hline $\begin{array}{l}\text { Prior disorder } \\
\text { covariate }\end{array}$ & No & Yes & No & Yes & No & No & Yes & No \\
\hline $\mathrm{N}$ & & 1,239 & & 726 & & & 708 & \\
\hline
\end{tabular}

1. Table only shows estimated coefficients on "any current psychiatric disorder."

2. All models adjust for survey design characteristics.

3. T-statistics are in parentheses and marginal effects (for probit models) are in brackets.

4. Models include the following covariates: Age categories, sub-ethnicity categories, number of household members under age 18, US citizen, immigrant, poor English proficiency, education categories, state unemployment rate, chronic physical health condition categories, and marital status.

5. Prior disorder defined as any psychiatric diagnosis with recent symptoms prior to previous year. 
Table 4 Effects of psychiatric disorders on labor market outcomes: Weighted regression results for Asian males

\begin{tabular}{|c|c|c|c|c|c|c|c|c|}
\hline & \multicolumn{3}{|c|}{ Employed } & \multicolumn{2}{|c|}{$\begin{array}{c}\text { Log of weeks worked among employed } \\
\text { individuals }\end{array}$} & \multicolumn{3}{|c|}{$\begin{array}{l}\text { At least one absence in the past month among } \\
\text { employed individuals }\end{array}$} \\
\hline \multicolumn{9}{|c|}{ PANEL A: EFFECTS OF PSYCHIATRIC DISORDER IN PAST 12 MONTHS } \\
\hline & (1) & (2) & (3) & (4) & (6) & (7) & (8) & (9) \\
\hline & Probit & Probit & $\begin{array}{l}\text { Bivariate } \\
\text { probit }\end{array}$ & OLS & TSLS & Probit & Probit & Bivariate probit \\
\hline $\begin{array}{c}\text { Any current } \\
\text { psychiatric } \\
\text { disorder } \\
\end{array}$ & $\begin{array}{c}-0.491 \text { *** } \\
(-2.27) \\
{[-0.129]} \\
\end{array}$ & $\begin{array}{l}-0.364 * \\
(-1.74) \\
{[-0.091]} \\
\end{array}$ & $\begin{array}{c}-0.079 \\
(-0.110) \\
{[-0.018]} \\
\end{array}$ & $\begin{array}{c}-0.082 \\
(-0.980)\end{array}$ & $\begin{array}{l}-0.527 \\
(-1.16)\end{array}$ & $\begin{array}{c}0.074 \\
(0.290) \\
{[0.020]} \\
\end{array}$ & $\begin{array}{c}-0.067 \\
(-0.300) \\
{[-0.017]} \\
\end{array}$ & $\begin{array}{l}-0.406^{*} \\
(-2.03) \\
{[-0.087]} \\
\end{array}$ \\
\hline $\begin{array}{l}\text { Prior disorder } \\
\text { covariate }\end{array}$ & No & Yes & No & Yes & No & No & Yes & No \\
\hline \multicolumn{9}{|c|}{ PANEL B: EFFECTS OF K10 MENTAL DISTRESS SCORE } \\
\hline & Probit & Probit & TSLS & OLS & TSLS & Probit & Probit & TSLS \\
\hline $\begin{array}{c}\text { K10 } \\
\text { Mental Distress } \\
\text { Score }\end{array}$ & $\begin{array}{l}-0.033 * \\
(-1.96) \\
{[-0.007]}\end{array}$ & $\begin{array}{l}-0.025 \\
(-1.59) \\
{[-0.005]}\end{array}$ & $\begin{array}{c}-0.007 \\
(-0.350)\end{array}$ & $\begin{array}{c}-0.009 * \\
(-1.82)\end{array}$ & $\begin{array}{l}-0.046 \\
(-0.95)\end{array}$ & $\begin{array}{c}0.026 \\
(1.44) \\
{[0.007]} \\
\end{array}$ & $\begin{array}{c}0.023 \\
(1.29) \\
{[0.006]}\end{array}$ & $\begin{array}{c}-0.006 \\
(-0.470)\end{array}$ \\
\hline $\begin{array}{l}\text { Prior disorder } \\
\text { covariate }\end{array}$ & No & Yes & No & Yes & No & No & Yes & No \\
\hline $\mathrm{N}$ & & 864 & & 717 & & & 709 & \\
\hline
\end{tabular}

Notes:

1. Table only shows estimated coefficients on "any current psychiatric disorder."

2. All models adjust for survey design characteristics.

3. T-statistics are in parentheses and marginal effects (for probit models) are in brackets.

4. Models include the following covariates: Age categories, sub-ethnicity categroies, number of household members under age 18, US citizen, immigrant, poor English proficiency, education categories, state unemployment rate, chronic physical health condition caegories, and marital status.

5. Prior disorder defined as any psychiatric diagnosis with recent symptoms prior to previous year 
Table 5 Effects of psychiatric disorders on labor market outcomes: Weighted regression results for Asian females

\begin{tabular}{|c|c|c|c|c|c|c|c|c|c|}
\hline & \multicolumn{3}{|c|}{ Employed } & \multicolumn{3}{|c|}{$\begin{array}{c}\text { Log of weeks worked among employed } \\
\text { individuals }\end{array}$} & \multicolumn{3}{|c|}{$\begin{array}{c}\text { At least one absence in the past month among } \\
\text { employed individuals }\end{array}$} \\
\hline \multicolumn{10}{|c|}{ PANEL A: EFFECTS OF PSYCHIATRIC DISORDER IN PAST 12 MONTHS } \\
\hline & (1) & $(2)$ & (3) & (4) & $(5)$ & $(6)$ & (7) & $(8)$ & (9) \\
\hline & Probit & Probit & $\begin{array}{l}\text { Bivariate } \\
\text { probit }\end{array}$ & OLS & OLS & TSLS & Probit & Probit & Bivariate probit \\
\hline $\begin{array}{l}\text { Any current } \\
\text { psychiatric } \\
\text { disorder }\end{array}$ & $\begin{array}{r}-0.110 \\
(-0.470) \\
{[-0.042]}\end{array}$ & $\begin{array}{c}-0.096 \\
(-0.420) \\
{[-0.036]}\end{array}$ & $\begin{array}{c}-0.021 \\
(-0.180) \\
{[-0.008]}\end{array}$ & $\begin{array}{l}-0.103 \\
(-1.27)\end{array}$ & $\begin{array}{l}-0.108 \\
(-1.40)\end{array}$ & $\begin{array}{c}-0.090 \\
(-0.830)\end{array}$ & $\begin{array}{c}0.031 \\
(0.190) \\
{[0.010]}\end{array}$ & $\begin{array}{c}0.061 \\
(0.360) \\
{[0.020]}\end{array}$ & $\begin{array}{c}0.132 \\
(0.270) \\
{[0.044]}\end{array}$ \\
\hline $\begin{array}{l}\text { Prior disorder } \\
\text { covariate }\end{array}$ & No & Yes & No & No & Yes & No & No & Yes & No \\
\hline \multicolumn{10}{|c|}{ PANEL B: EFFECTS OF K10 MENTAL DISTRESS SCORE } \\
\hline & Probit & Probit & TSLS & OLS & OLS & TSLS & Probit & Probit & TSLS \\
\hline $\begin{array}{c}\text { K10 } \\
\text { Mental Distress } \\
\text { Score }\end{array}$ & $\begin{array}{c}-0.007 \\
(-0.530) \\
{[-0.003]}\end{array}$ & $\begin{array}{c}-0.006 \\
(-0.500) \\
{[-0.002]}\end{array}$ & $\begin{array}{c}0.007 \\
(0.680)\end{array}$ & $\begin{array}{l}-0.008 \\
(-1.31)\end{array}$ & $\begin{array}{l}-0.008 \\
(-1.35)\end{array}$ & $\begin{array}{c}-0.008 \\
(-0.600)\end{array}$ & $\begin{array}{c}0.018 \\
(1.34) \\
{[0.006]}\end{array}$ & $\begin{array}{c}0.019 \\
(1.46) \\
{[0.006]}\end{array}$ & $\begin{array}{l}0.022 \\
(1.48)\end{array}$ \\
\hline $\begin{array}{l}\text { Prior disorder } \\
\text { covariate }\end{array}$ & No & Yes & No & No & Yes & No & No & Yes & No \\
\hline $\mathrm{N}$ & & 954 & & & 626 & & & 618 & \\
\hline
\end{tabular}

1. Table only shows estimated coefficients on "any current psychiatric disorder."

2. All models adjust for survey design characteristics.

3. T-statistics are in parentheses and marginal effects (for probit models) are in brackets.

4. Models include the following covariates: Age categories, sub-ethnicity categories, number of household members under age 18, US citizen, immigrant, poor English proficiency, education categories, state unemployment rate, chronic physical health condition categories, and marital status.

5. Prior disorder defined as any psychiatric diagnosis with recent symptoms prior to previous year. 
